\title{
Integrated cylinder pressure measurement for gas engine control
}

\begin{abstract}
Closed loop control based on cylinder pressure measurement has been investigated for over 20 years. The aim has been to improve combustion control and online engine diagnostics. However the price of cylinder pressure sensors and the high demands on processor capacity have been preventing the development. Lately however sensor technologies have improved and as a result costs have been reduced. The purpose of this work is to show the large amount of information that can be read out from the cylinder pressure curve and to evaluate a cylinder pressure based closed loop engine control.
\end{abstract}

Key words: gas engine, cylinder pressure, pressure sensor

\section{Sterowanie pracą silnika gazowego z wykorzystaniem układu do pomiaru ciśnienia w cylindrze}

\begin{abstract}
Od ponad 20 lat prowadzone sa prace rozwojowe dotyczace wykorzystania pomiaru ciśnienia w cylindrze, do sterowania parametrami silnika ze sprzężeniem zwrotnym. Celem tych prac jest zwiększenie kontroli nad przebiegiem spalania oraz diagnozowanie silnika on-line. Ograniczeniem zastosowania takich układów jest duża cena czujników oraz znaczne wymagania odnośnie do wydajności wykorzystywanych procesorów. Jednak obserwowany w ostatnim czasie rozwój technologii spowodowat zmniejszenie kosztów ich wytwarzania. Celem niniejszego artykułu jest prezentacja możliwości wykorzystania informacji pochodzacej z czujnika ciśnienia w cylindrze silnika spalinowego oraz adaptacja jej do sterowania praca silnika.
\end{abstract}

Słowa kluczowe: silnik gazowy, ciśnienie spalania, czujnik ciśnienia

\section{Introduction}

Constantly increasing demands on low emissions, low fuel consumption and increased MTBF can be met with improved combustion control and online diagnostics. Higher efficiency on Diesel- and Gas Engines can only be reached with advanced sensors.

IMES GmbH has successful developed their cylinder pressure sensor type HTT for serial production, which was introduce first time at CIMAC congress 2001. In the meantime more than 20,000 sensors were produced. Essential for the use is the long life stability @ 16,000-20,000 h and a low market price accepted by engine manufacturer for closed loop control applications.

A modular electronic concept of data acquisition and visualisation for combustion data for application on Diesel and Gas Engine was developed together with Wärtsilä Service Finland. The digital system for data acquisition from the cylinder pressure sensors so that, as the fundamental variable that determines a combustion engine's operation state like Pmax, IMEP, knocking and misfire, cylinder pressure data can be acquired continuously an in real-time and used for service application round the world.

\section{Longlife cylinder pressure sensor type HTT}

The objective was to develop a high temperature pressure sensor, which will withstand the extreme hostile environment on the gas engine process.

In addition to the general required performance characteristics as low hysteresis, high linearity, and low temperature dependency cylinder pressure sensors must fulfil the following requirements:

\section{Wprowadzenie}

Sterowanie i diagnostyka silnika z wykorzystaniem sygnału ciśnienia w cylindrze stwarza możliwość spełnienia zwiększanych wymagań dotyczących emisji związków toksycznych spalin i zużycia paliwa. Jedną z możliwości zwiększenia sprawności silników o zapłonie samoczynnym i silników gazowych jest zastosowanie w procesie sterowania nowoczesnych i zaawansowanych technologicznie czujników ciśnienia.

Firma IMES GmbH sukcesywnie udoskonala czujniki (typu HTT) do pomiaru ciśnienia w cylindrze silnika, co w konsekwencji ma doprowadzić do produkcji seryjnej. Pierwsza prezentacja tych czujników odbyła się na Kongresie CIMAC w 2001 r.; od tego czasu wyprodukowano ich ponad 20000 szt. Zasadniczą zaletą czujników firmy IMES jest znaczny czas stabilnej pracy $16000-20000 \mathrm{~h}$ i niska cena rynkowa akceptowana przez przemysł motoryzacyjny. To właśnie te cechy powodują, że mogą być one wykorzystywane do sterowania pracą silnika.

Firma IMES, wspólnie z Wartsila Service Finland, prowadziła prace rozwojowe nad systemem do akwizycji i wizualizacji parametrów procesu spalania silników o zapłonie samoczynnym i silników gazowych. Stworzony system umożliwia określenie następujących parametrów: maksymalnego ciśnienia spalania, średniego ciśnienie użytecznego, wykrywanie wypadania zapłonu oraz wykrywanie spalania stukowego. Parametry procesu spalania mogą być rejestrowane w sposób ciągły w czasie rzeczywistym i następnie wykorzystywane do obsługi serwisowej silnika. 
In addition to the general required performance characteristics as low hysteresis, high linearity, and low temperature dependency cylinder pressure sensors must fulfil the following requirements:

1. Resistance to extreme variation of media temperature (RT-1700 ${ }^{\circ} \mathrm{C}$ ).

2 . Resistance to high vibration during heavy knocking.

3. Extreme high load cycles $\left(5 \times 10^{8}\right.$ to $10^{9}$ full load cycles $)$.

4. Long term stability up to temp. of $300^{\circ} \mathrm{C}$.

5 . Small temperature shock drift of pressure signal.

6. Small dimensions (not larger than a spark plug).

\section{Calculation of mechanical performance}

Using the Finite Element Method (FEM) the measure cell is designed for extreme full load use (Fig. 1). The light areas are those with high load-bearings, the darker areas show parts of the measure cell with lower load-bearings. Using the FEM-calculations (Fig. 2) the measure cell/membrane was designed to the optimum dimensions.

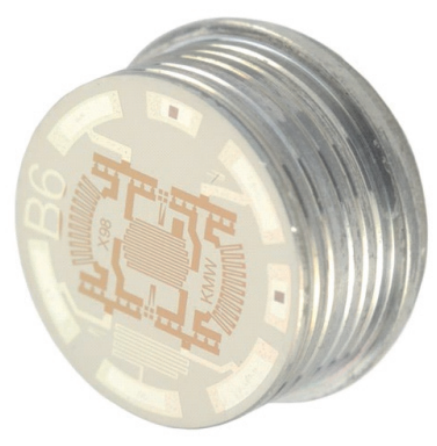

Fig. 1. Measuring cell

Rys. 1. Element pomiarowy czujnika

\section{Sensor type}

The most commenly used sensor type is the HTT sensor (Fig. 3) with thread M14×1.25 HTT long life cylinder pressure sensor is mounted direct at the cylinder head (Fig. 4), which is designed for long term, continuous operation at up to 300 bar and $300{ }^{\circ} \mathrm{C}$. During long-term tests on different engines the drifts in span and offset were minor.

The CPS sensor (Fig. 5) with thread M10 $\times 1$ is specially designed for high speed gas engines with small installation places at cylinder head.

HTT- and CPS sensors have been designed for 16.000 operating hours on gas engines.

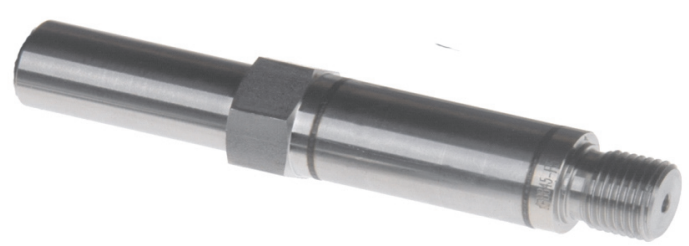

Fig. 3. Sensor head HTT-Sensor Rys. 3. Czujnik ciśnienia HTT

\section{Czujniki ciśnienia w cylindrze (typu HTT)}

Rozwój czujników ciśnienia typu HTT firmy IMES był ukierunkowany na przystosowanie ich do zastosowań w niekorzystnych warunkach oddziaływania gazów spalinowych. Oprócz typowych wymagań stawianych czujnikom, takich jak mała histereza, duża linearyzacja, odporność na wysoką temperaturę, muszą one spełniać następujące warunki:

- duża odporność na zmiany temperatury $\left(\mathrm{RT}-1700{ }^{\circ} \mathrm{C}\right)$,

- odporność na drgania,

- trwałość $\left(5 \times 10^{8}\right.$ do $10^{9}$ pełnych cykli obciążeniowych),

- długi czas stabilnej pracy w temperaturze do $300^{\circ} \mathrm{C}$,

- mały dryft sygnału pod wpływem nagłych zmian temperatury,

- małe wymiary.

\section{Obliczenia właściwości mechanicznych}

Wykorzystując metodę elementów skończonych (MES), zaprojektowano optymalne wymiary membrany pomiarowej z uwzględnieniem jej maksymalnego obciążenia (rys. 1 i 2). Widoczne na rysunku ciemne obszary to część pomiarowa wykorzystywana podczas dużego obciążenia czujnika, natomiast jasne obszary - podczas mniejszego obciążenia.

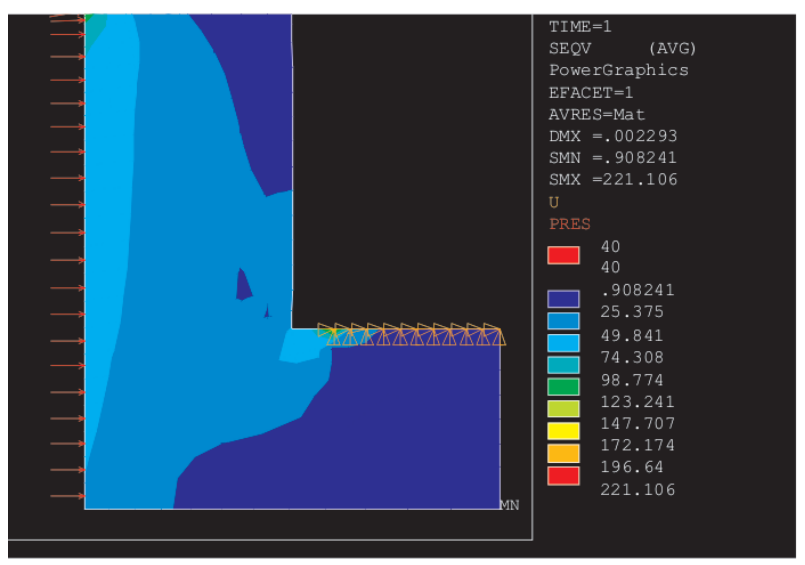

Fig. 2. FEM calculation

Rys. 2. Obliczenia mechaniczne czujnika z wykorzystaniem MES

\section{Rodzaje czujników}

Najczęściej stosowanym czujnikiem jest czujnik HTT z gwintem M14×1,25 (rys. 3). Czujnik taki jest montowany w głowicy silnika (rys. 4) i zaprojektowany do długotrwałej pracy ciągłej; ciśnienie robocze do 300 bar i temperatura do $300{ }^{\circ} \mathrm{C}$. Doświadczalnie, podczas długotrwałych prób przeprowadzonych na różnych silnikach stwierdzono, że dryft sygnału z czujnika jest nieznaczny. Czujnik CPS z gwintem M10×1 zaprojektowano specjalnie do zastosowań w szybkoobrotowych silnikach gazowych (rys. 5). Oba czujniki HTT i CPS są przeznaczone do silników gazowych i zaprojektowane do pracy ciągłej przez $16000 \mathrm{~h}$.

\section{Położenie czujnika}

Czujniki mogą być montowane w dwojaki sposób (rys. 6 i 7), przy czym w przypadku zamocowania przedstawionego 


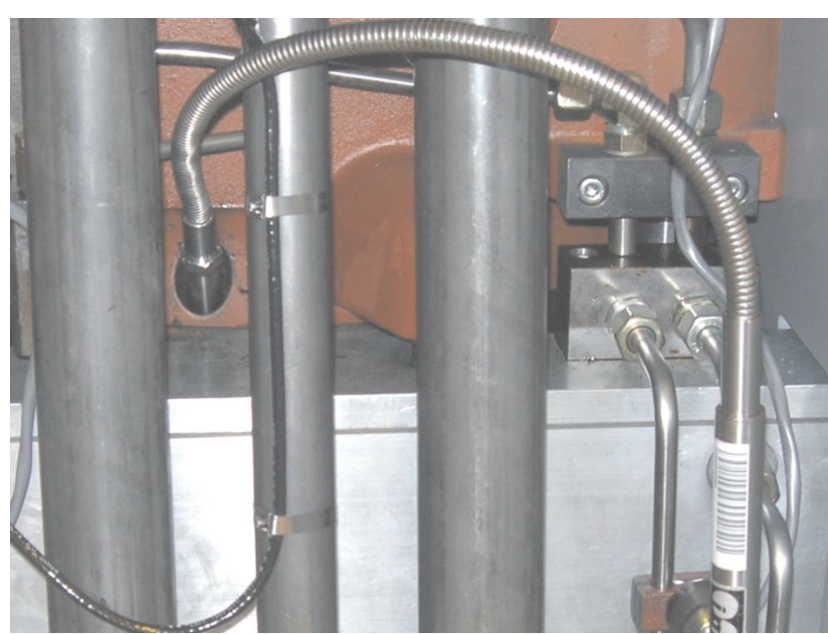

Fig. 4. Installation place HTT-sensor Rys. 4. Zamontowany czujnika HTT

\section{Sensor position}

Generally there are two possibilities for the installation position of cylinder pressure sensors: Head mounted or back mounted. If sensor is back mounted installed there are some possibilities of pipe vibrations.

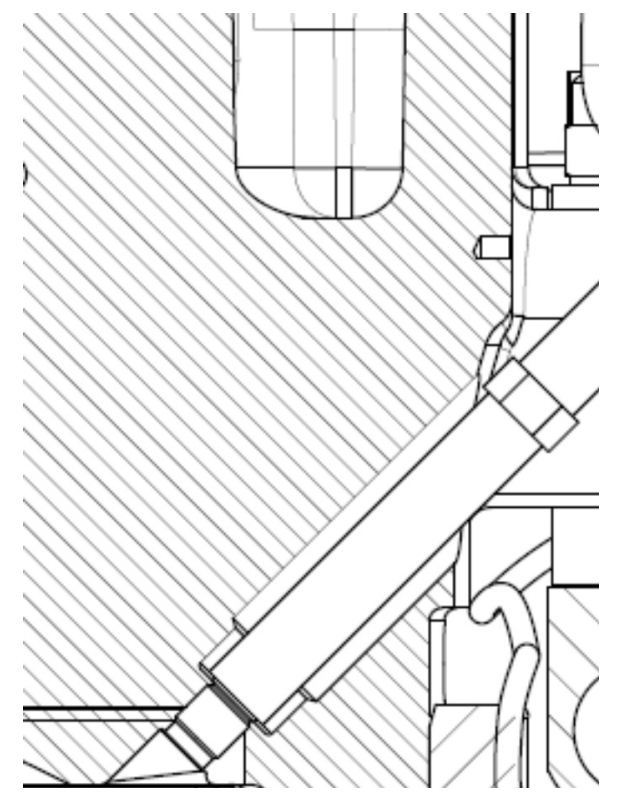

Fig. 6. Head mounted installation

Rys. 6. Zamontowany czujnik

\section{Longlife stability}

During a long-term operation the sensors were taken off from the engine after $16,000 \mathrm{~h}$ and sent back to IMES for checking the original calibration data (Fig. 7 and 8). The span and offset of each sensor was measured over the full temperature range. The experienced drifts in span and offset were minor, which is very important fort the use on control loops on engines.

The Signal Conditioning Unit (SCU) has the opportunity to compensate offset change. This function can be switched $\mathrm{ON}$ or OFF at workshop.

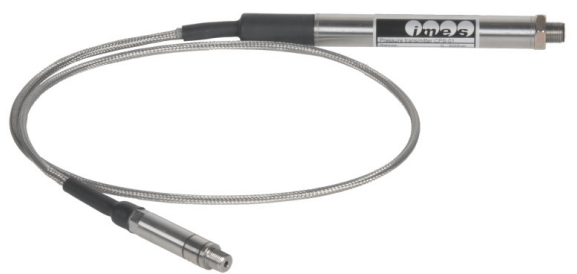

Fig. 5. CPS-01 Sensor

Rys. 5. Czujnik CPS-01

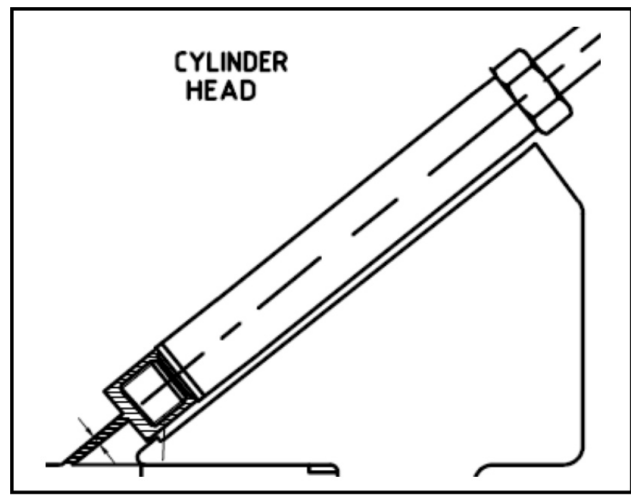

Fig. 7. Back mounted installation

Rys. 7. Sposób zamontowania czujnika z kanałem przeptywowym

z na rys. 7, istnieje możliwość wystąpienia drgań czynnika w kanale łączącym komorę spalania i przestrzeń pod membraną pomiarową czujnika.

\section{Trwałość czujników}

Przeprowadzono próbę trwałościową czujników (16 000 h), po czym czujniki zdemontowano i wysłano do firmy IMES w celu sprawdzenia kalibracji (rys. 7 i 8). Sprawdzono rozrzut i uchyb sygnału w całym zakresie temperatury. Wartości były nieznacznie różne od prawidłowych, co jest bardzo ważne w aspekcie wykorzystania czujnika do sterowania parametrami pracy silnika w pętli sprzężenia zwrotnego. Za pomocą modułu przygotowania sygnału SCU (Signal Conditioning Unit) istnieje możliwość kompensacji zmian uchybu.

\section{Dokładność czujników}

Wykorzystanie czujników w procesie sterowania silnika oraz obliczenia termodynamiczne wymagają dużej dokładności wskazań czujników ciśnienia. W Large Engine Competence Center w Austrii w 2007 r. wykonano badania porównawcze czujnika IMES CPS-01 i piezoelektrycznego czujnika ciśnienia firmy AVL typ QC34C (rys. 10 i 11). Badania wykonano na jednocylindrowym silniku gazowym (prędkość obrotowa silnika $1500 \mathrm{obr} / \mathrm{min}, \mathrm{P}_{\mathrm{mi}}=12$ bar). Przeprowadzony eksperyment porównawczy dał pozytywny wynik i zaobserwowano zadowalającą korelację wyników.

\section{Wizualizacja on-line i akwizycja danych z czujnika ciśnienia $\mathbf{w}$ cylindrze dla zastosowań obsługi serwisowej}

Równocześnie z pracami rozwojowymi nad czujnikami ciśnienia prowadzono prace nad specjalnym oprogramowaniem systemu do akwizycji danych uzyskanych z pomiaru 


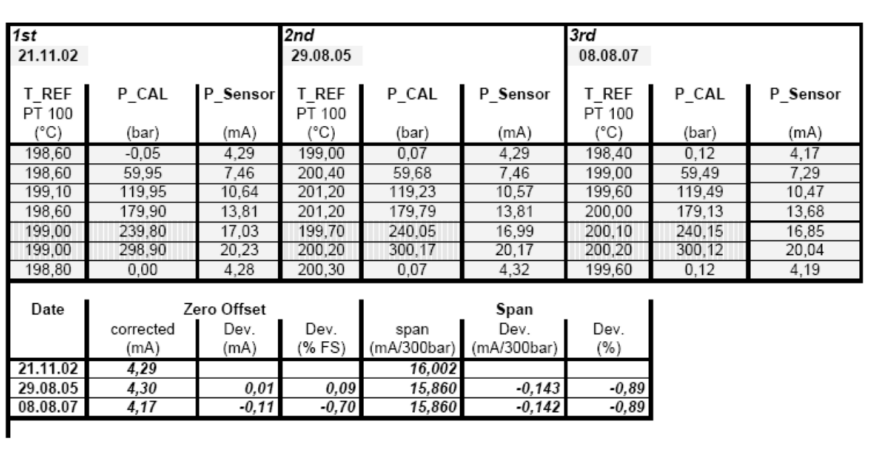

Fig. 8. Calibration data

Rys. 8. Dane kalibracyjne czujnika

\section{Accuracy of sensor}

For future application on control loops it necessary to have a good long life stability- and a good accurcy of sensor for thermodynamic calculations. At the Large Engine Competence Center (LEC) at Graz - Austria comparisons between IMES CPS-01 sensors and high accuracy piezoelectric type sensors (AVL Typ:QC34C) were done in November 2007 (Fig. 10 and 11).

The comparison of the CPS-01 sensors to the water cooled piezo-electric reference sensor showed good results. The measurements were done on a single cylinder gas engine (1500 rpm)@ 12 bar $\mathrm{P}_{\mathrm{mi}}$.

\section{Marine Classification}

The HTT-04CA has Marine type approval of Bureau Veritas and Dets Norske Veritas Other marine class societies will follow.

\section{Online data acquisition and visualisation system for combustion pressure for service application}

In parallel, the company has developed a digital system for data acquisition from the cylinder pressure sensors so that, as the fundamental variable that determines a combustion engine's operation state like $\mathrm{P}_{\max }$, IMEP, knocking and misfire, cylinder pressure data can be acquired continuously an in real-time and so more effectively used as an engine control parameter.

To afford this benefit to service applications, the CMS (Fig. 12) was designed to measure, monitor and store combustion pressure signals referenced to the crank angle position of different types of constant medium speed gas engines (generator application). The calculated information is available to an industrial Notebook PC via CAN- bus. The CMS includes 21 pc. cylinder pressure sensors and terminal boxes which are delivered in a portable measurement device where all components can be stored during transportation.

The data acquisition- and visualisation software is designed for use on vee or inline configuration engines with 4 to 20 cylinders. All needed parameter for the engine types of W32DF, W34SG and W50DF are already fixed and can be selected and activated in a few seconds.

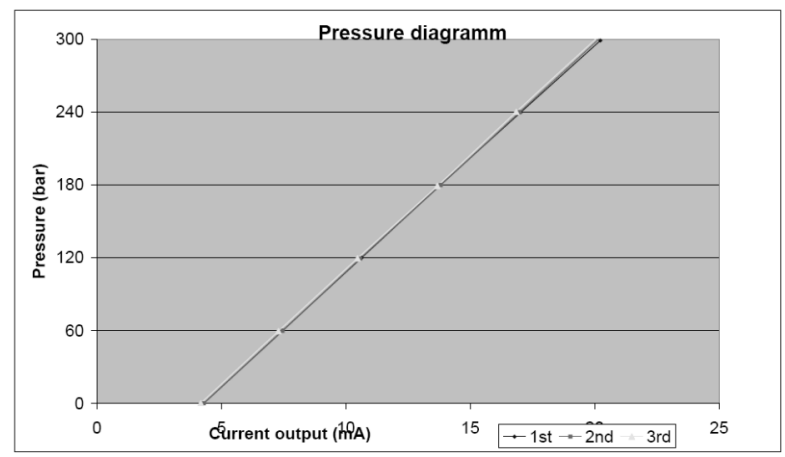

Fig. 9. Comparison of calibration data

Rys. 9. Porównanie danych kalibracyjnych czujnika

ciśnienia w cylindrze silnika. Program umożliwia monitorowanie i określenie w czasie rzeczywistym parametrów pracy silnika, np. maksymalnego ciśnienia w cylindrze, średniego ciśnienia użytecznego, wykrywanie spalania stukowego i wypadania zapłonów. Wykorzystując takie oprogramowanie, zaprojektowano i wykonano układ CMS (Continuous, Combustion Measurement System - system do ciągłego pomiaru spalania) do pomiaru i rejestracji sygnału z czujnika ciśnienia w cylindrze, jako funkcji kąta położenia wału korbowego silnika. System CMS jest dedykowany do silników gazowych średnioobrotowych, pracujących ze stałą prędkością obrotową (stosowanych do napędu generatorów). Dane są rejestrowane na dysku komputera połączonego $\mathrm{z}$ układem przez magistralę CAN-bus. Układ CMS zawiera 21 czujników ciśnienia i stację końcową, elementy te są

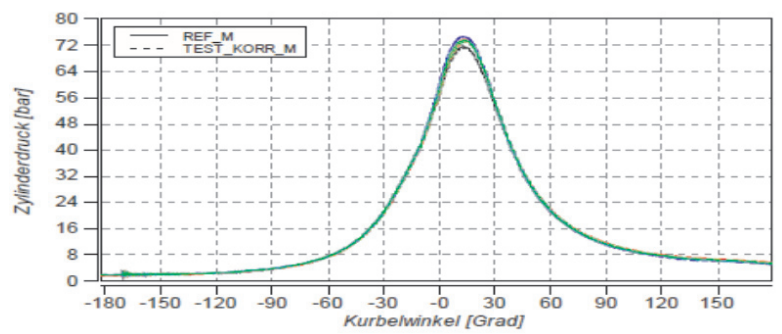

Fig. 10. Comparison CPS-01 sensors and reference sensor Rys.10. Porównanie pomiarów ciśnień w cylindrze czujników CPS-01 i piezoelektrycznego AVL typ QC $34 C$

\begin{tabular}{|c|c|c|c|c|c|}
\hline & & 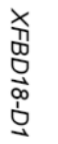 & 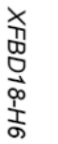 & 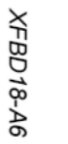 & 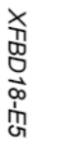 \\
\hline $\mathrm{Pi}$ & bar & 0.44 & 0.75 & 0.36 & 0.52 \\
\hline $\mathrm{PiH}$ & bar & 0.41 & 0.88 & 0.21 & 0.58 \\
\hline PiL & bar & 0.03 & -0.1 & 0.15 & -0.0 \\
\hline Brennbeginn & Grad & 0.85 & -0.2 & 1.65 & 1.30 \\
\hline MFB_5\% & Grad & 0.85 & -0.2 & 1.65 & 1.30 \\
\hline MFB $10 \%$ & Grad & 0.75 & 0.20 & 1.25 & 1.05 \\
\hline MFB_50\% & Grad & 0.60 & 1.25 & 0.75 & 1.15 \\
\hline MFB $90 \%$ & Grad & 0.75 & 6.70 & 0.45 & 3.00 \\
\hline Spitzendruck & bar & -0.3 & -0.6 & -0.0 & -0.4 \\
\hline Lage_Spitzendruck & Grad & 0.40 & 0.40 & 0.40 & 1.40 \\
\hline Schwerpunkt & Grad & 0.65 & 1.50 & 0.80 & 1.35 \\
\hline dQH MAX & $\% /$ deg & 0.02 & -0.2 & 0.07 & -0.0 \\
\hline dQH MAX LAGE & Grad & 0 & 0.40 & 0 & 0 \\
\hline
\end{tabular}

Fig. 11. Comparison data

Rys. 11. Porównanie parametrów czujników 


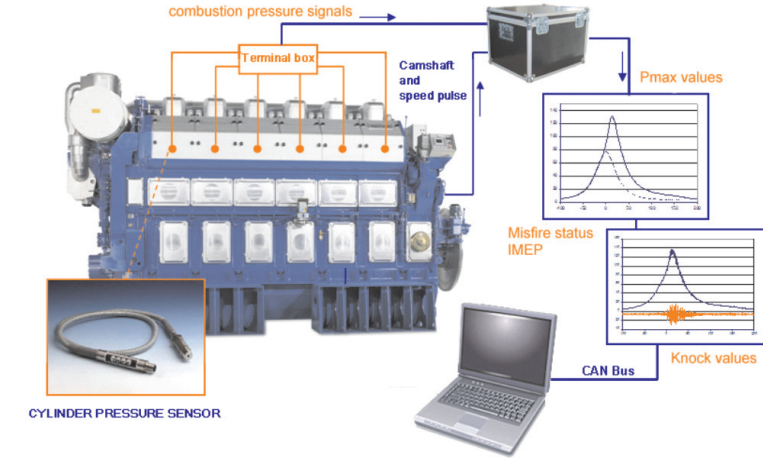

Fig. 12. System overview CMS

Rys. 12. Uktad CMS

The main window of the visualisation software offers the possibility of selecting advanced monitoring functions in the following four diagrams:

- Pressure diagram

- Working cycle

$-\mathrm{P}_{\max }$ balance

- IMEP balance

- COV of IMEP

- System check Sensors, -Pulse, -Data acquisition

Main window/glówne okno

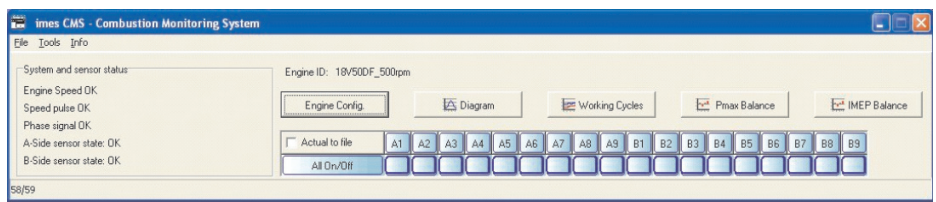

$\mathrm{P}_{\max }$ balance/rozrzuty maksymalnych ciśnień w cylindrze

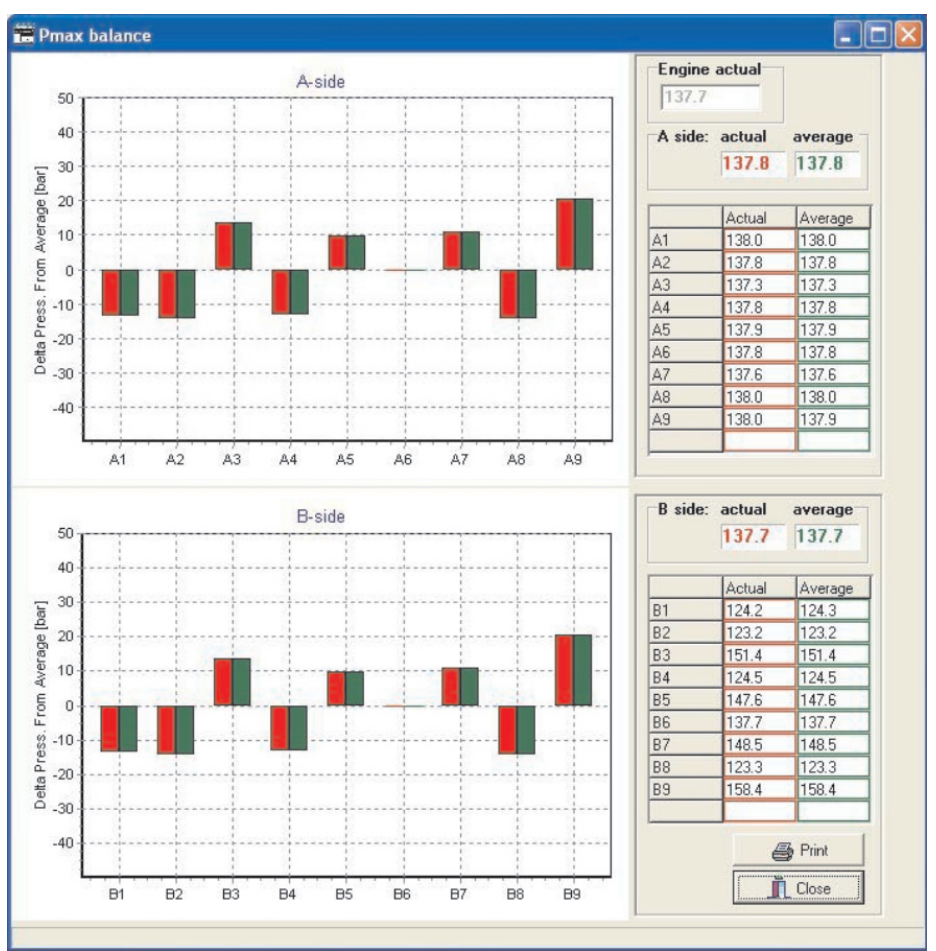

przystosowane do zastosowań mobilnych, zabezpieczone przed ewentualnymi uszkodzeniami w transporcie.

Oprogramowanie do akwizycji i wizualizacji parametrów pracy silnika jest przystosowane do silników o liczbie cylindrów 4-20 w układzie rzędowym lub widlastym. Wszystkie wymagane dane dla silników typu W32DF, W34SG, i W50DF są wprowadzone do systemu i mogą być aktualizowane na bieżąco.

Główne okno oprogramowania do wizualizacji danych umożliwia prezentację czterech wybranych wykresów:

- przebiegu ciśnienia w cylindrze (również wielu cykli),

- rozrzutu maksymalnych wartości ciśnienia w poszczególnych cylindrach,

- rozrzutu wartości średniego ciśnienia użytecznego w poszczególnych cylindrach,

- COV średniego ciśnienia użytecznego (współczynnik zmian średniego ciśnienia użytecznego),

- dane kontrolne (diagnostyczne) czujników,

- zarejestrowane dane.

\section{Praktyczne wykorzystanie}

Do wykrywania zjawiska spalania stukowego w systemie CMS wykorzystuje się czujniki przyspieszenia i
Pressure diagram/wykres ciśnienia $w$ cylindrze

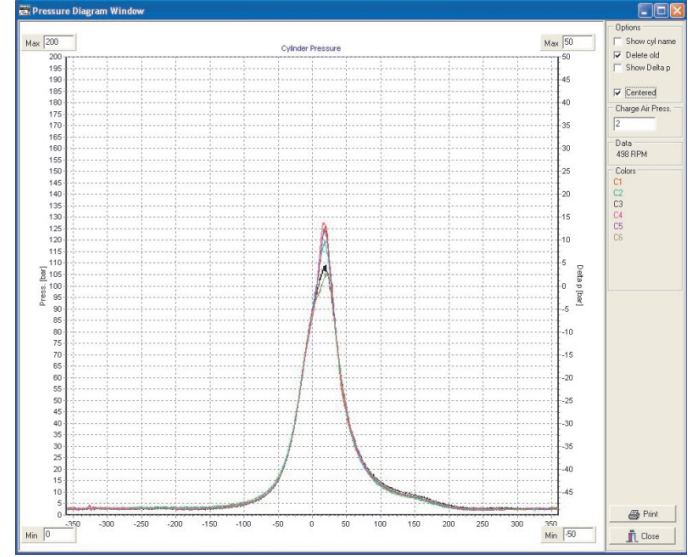

Working cycle/przebieg parametrów pracy silnika

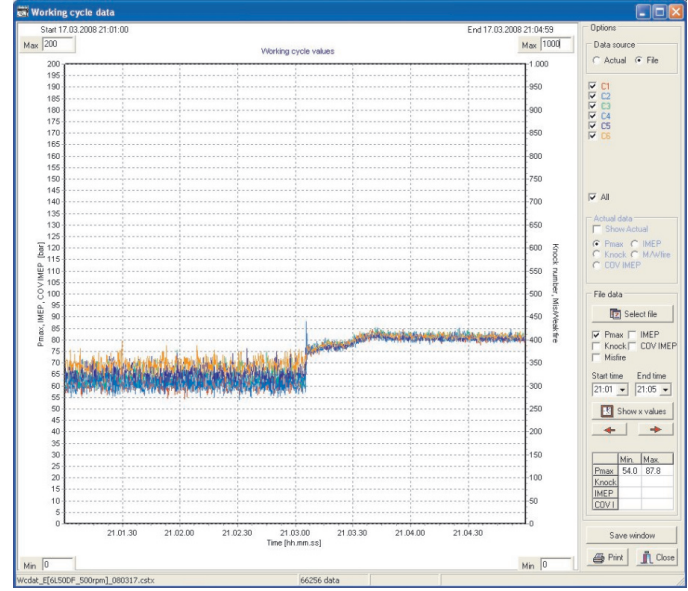

Fig. 13. CMS functions

Rys. 13. Widok okien dialogowych układu CMS 


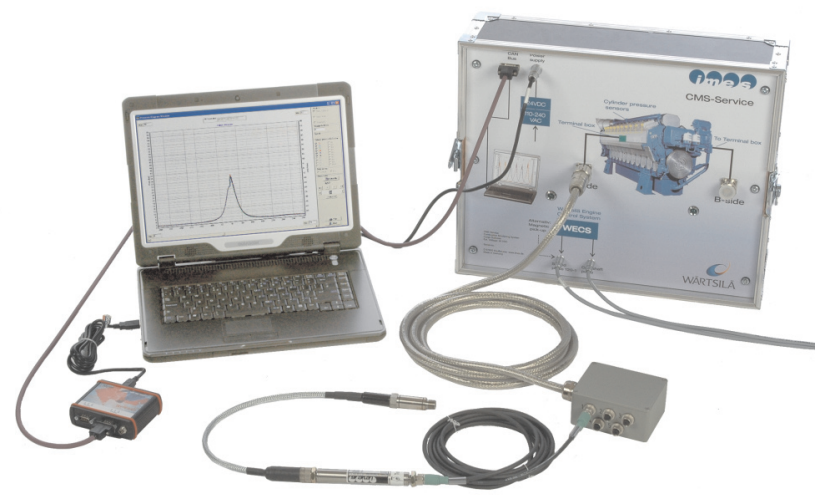

Fig. 14. CMS Cargo box components

Rys. 14. Elementy uktadu CMS

The following data: $\mathrm{P}_{\max }$, knocking misfire, IMEP, COV of IMEP will be automatically saved after start of visualisation software and can be monitored also in offline mode.

\section{Practical application}

CMS with cylinder pressure sensors can detect knocking much more precise than acceleration sensors (Fig. 16 and 17). The service engineer can adjust existing knock detection system with CMS. Also heavy knocking will be detected much earlier with CMS.

The visualisation software function (Fig. 18) helps applica-

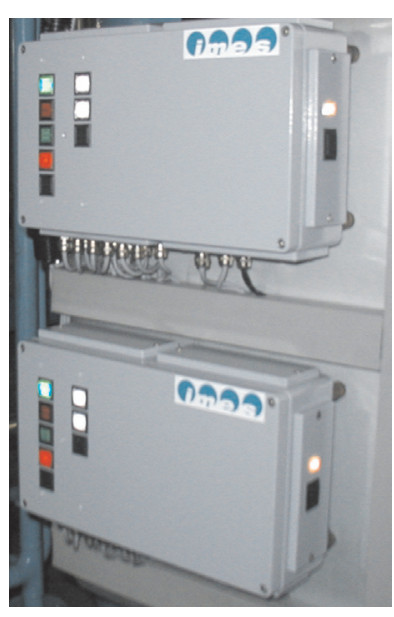

Fig. 15. CMS for stationary application

Rys. 15. Uktad CMS do stacjonarnych zastosowań tion engineer to optimise cylinder balancing for decreasing mechanical impact of engine.

The compression pressure of all cylinder should have max. deviation of \pm 2 bar at $15^{\circ} \mathrm{CA}$ (Fig. 19). With the help of this software function detected piston rings can be early detected.

\section{Possibilities of pressure controlled engines}

Cylinder pressure analysis allows to substitute conventional monitoring system: Acceleration sensors, lambda sensors, temperature sensors for exhaust gas temperature. Control loops with cylinder pressure sensors will be applied in the first step for injection control, knock detection and for air-/fuel ratio.

The a.m. list shows all possible applications with cylinder pressure: [1]:

- Cylinder balancing

- Detection of high peak pressure

- Knock and pre-ignition detection

- Weak- and misfire detection

- Fault detection/ diagnostics

- Ignition timing control

- Pilot optimization

- Visualization of different cylinder pressure related engine parameters czujnik ciśnienia w cylindrze; rozwiązanie to jest bardziej precyzyjne od systemów wykorzystujących tylko czujniki przyspieszenia (rys. 16 i 17). W układzie CMS istnieje możliwość wykorzystania zamontowanych na silniku czujników wykrywania spalania stukowego (rys. 16 i 17).

Optimisation of knocking (acceleration sensors)
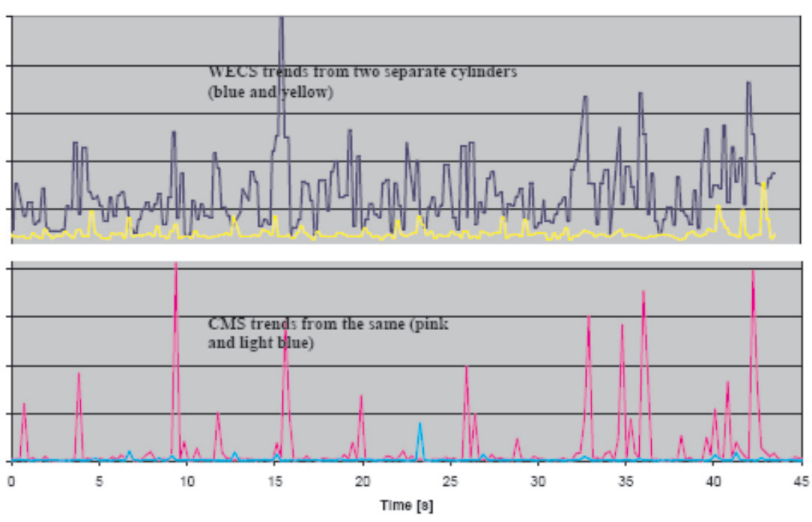

Fig. 16. Comparison acceleration sensors and CMS

Rys. 16. Porównanie sygnałów wykrywania spalania stukowego za pomoca czujnika przyspieszenia i systemu CMS

\section{Load reduction after knock alarm}
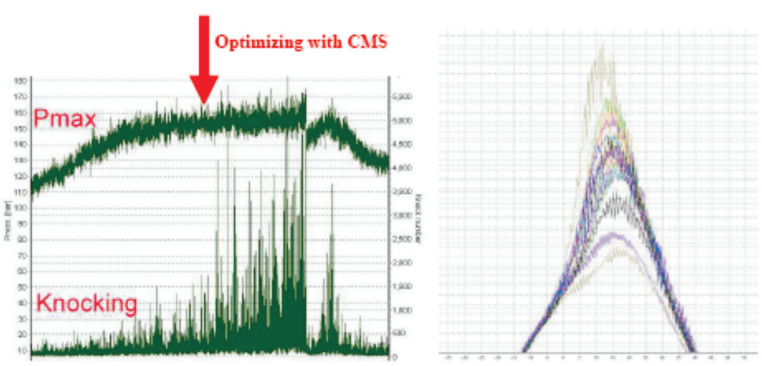

Fig. 17. Knock numbers calculated by CMS

Rys. 17. Wyznaczanie spalania stukowego $w$ systemie CMS

Cylinder balancing; Engine stability

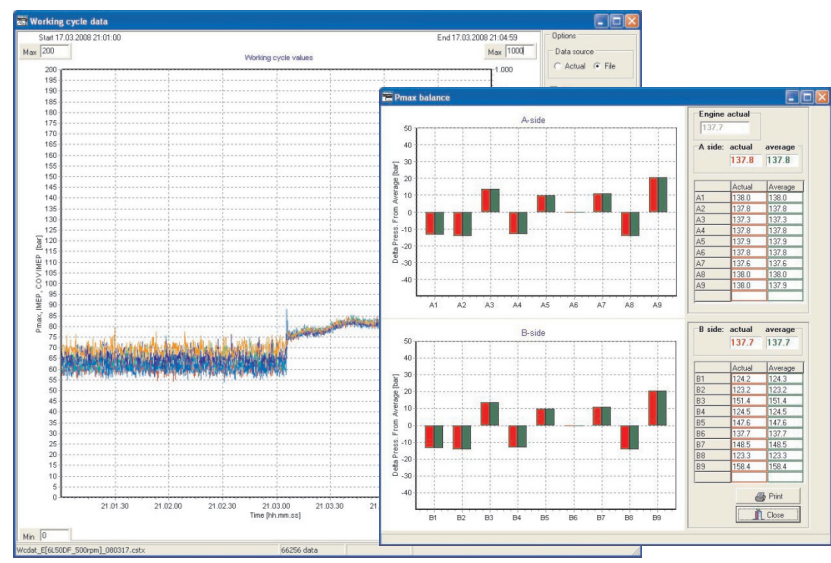

Fig. 18. Working cycle $\mathrm{P}_{\max }$ and $\mathrm{P}_{\max }$ balancing

Rys. 18. Przebiegi ciśnienia $w$ cylindrze, rozrzut $P_{\max } w$ poszczególnych cylindrach silnika 
Check compresion pressure

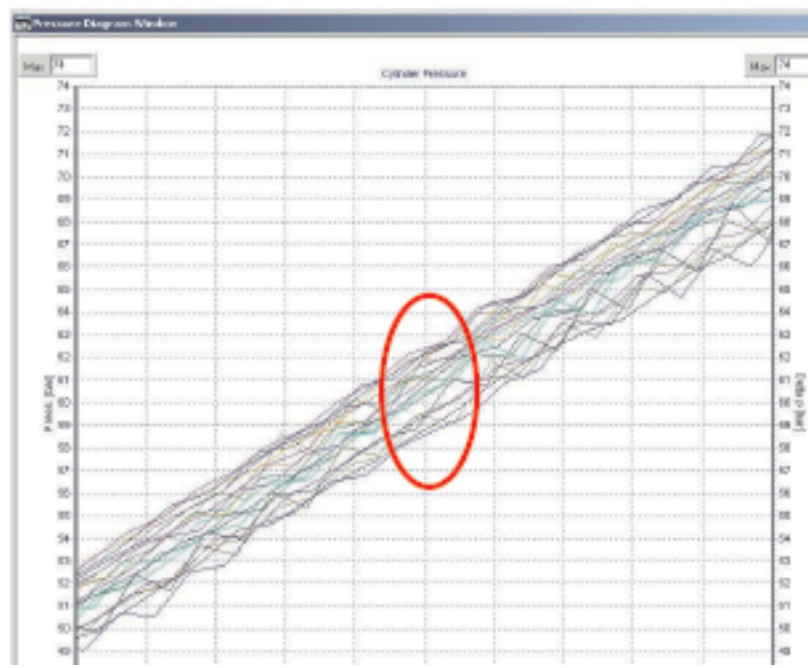

Fig. 19. Compare pressure at $15^{\circ} \mathrm{CA}$ before TDC

Rys. 19. Porównanie ciśnienia w cylindrze (położenie wału korbowego $15^{\circ}$ przed $\left.G M P\right)$

- Air/fuel ratio control

- Exhaust gas recirculation control

- Camshaft position sensing

- Providing indicated torque signal

- Simplified calibration/ reduces the need of mapping

- Warranty reduction

- Turbo surge prevention

The conventional method for exhaust gas temperature for mixture control is very old with delay reaction time. Closed loop control with cylinder pressure can detected mis- or weak fire and can start counter measure procedures.

Acceleration sensors will be applied for conventional knock detection. The influence of interference signal is high. Light- and medium knocking can be detected insufficient, which generate engine damage.

Knock detection with cylinder pressure sensors is very precise at light- and medium knocking for application on closed lop control.

Figure 20 shows overview about possibilities for to analyze cylinder pressure signals.

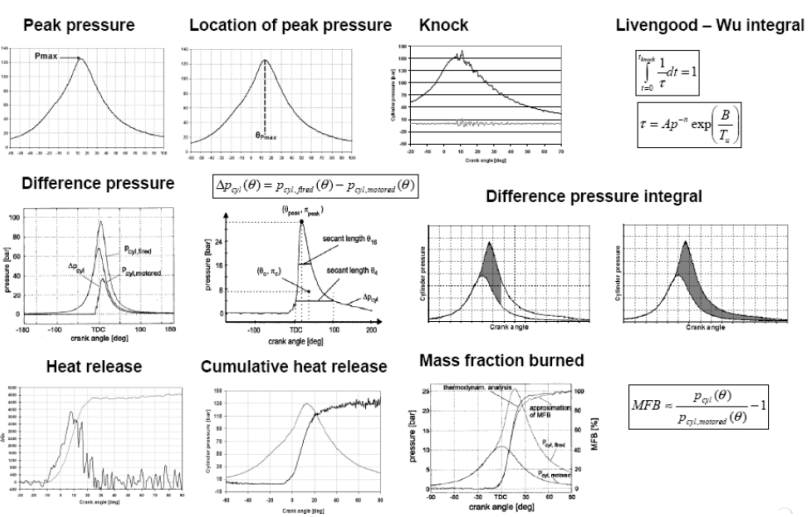

Fig. 20. Methods for analyzing cylinder pressure signal Rys. 20. Metody analizy sygnału ciśnienia w cylindrze
Oprogramowanie do wizualizacji i rejestracji umożliwia wyrównanie maksymalnych ciśnień w poszczególnych cylindrach silnika. Dzięki temu różnice między wartościami ciśnienia w poszczególnych cylindrach nie przekraczają 2 bar (dla położenia wału korbowego $15^{\circ}$ przed GMP) (rys. 19). Ponadto wizualizacja ciśnień w cylindrze pozwala na szybkie wykrycie uszkodzenia pierścienia tłokowego.

\section{Możliwości sterowania silnika z wykorzysta- niem pomiaru ciśnienia $w$ cylindrze}

Pomiar i analiza przebiegu ciśnienia w cylindrze moga zastąpić wiele czujników wykorzystywanych w procesie sterowania silnika, np. czujnik przyspieszenia (wykrywanie spalania stukowego), sondę lambda, czujnik temperatury spalin. Sygnał z pomiaru ciśnienia w cylindrze $\mathrm{w}$ pierwszej kolejności powinien być wykorzystany do sterowania procesem wtrysku paliwa i wykrywania spalania stukowego. Pomiar ciśnienia w cylindrze może być wykorzystany do następujących zastosowań:

- wyrównanie ciśnienia w poszczególnych cylindrach silnika,

- wykrywanie gwałtownego zwiększenia ciśnienia w cylindrze,

- wykrywanie spalania stukowego,

- wykrywanie wypadania zapłonu,

- wykrywanie awarii silnika,

- wizualizacja przebiegów ciśnienia w cylindrze wraz z innymi parametrami pracy silnika,

- kontrola składu mieszanki,

- sterowanie recyrkulacją spalin,

- ustalenie aktualnego położenia wału korbowego silnika,

- ułatwienie sterowania pracą silnika, ograniczenie potrzeby sterowania według mapy zapisanej w jednostce sterującej,

- regulacja turbodoładowania.

Wykorzystanie pomiaru temperatury spalin do sterowania składem mieszanki charakteryzuje się opóźnioną reakcją silnika i jest metodą przestarzałą. Sterowanie z wykorzystaniem sygnału $\mathrm{z}$ pomiaru ciśnienia $\mathrm{w}$ cylindrze pozwala na wykrywanie wypadania zapłonów. Czujniki przyspieszenia mogą być wykorzystywane do wykrywania spalania stukowego, jednak wtedy może pojawić się zjawisko nakładania się sygnałów. Dlatego dla pewnych zakresów wypadania zapłonu (tzw. light i medium) metoda ta nie jest wystarczająca; w konsekwencji może doprowadzić do uszkodzenia silnika. W związku z tym efektywniejsze jest wykrywanie spalania stukowego z wykorzystaniem sygnału ciśnienia w cylindrze. Na rysunku 20 przedstawiono możliwości wykorzystania sygnału ciśnienia w cylindrze.

\section{Wykorzystanie pomiaru ciśnienia w cylindrze. Wnioski z projektu Pilot Project 50 DF}

\section{Kontrola spalania stukowego}

Na rysunku 21 przedstawiono porównanie wykrywania spalania stukowego metodą konwencjonalną i metodą $\mathrm{z}$ wykorzystaniem pomiaru ciśnienia w cylindrze. Przewiduje się, że dzięki opracowanej metodzie w przyszłości możliwe będzie opracowanie strategii sterowania ograniczającej zjawisko spalania stukowego. 


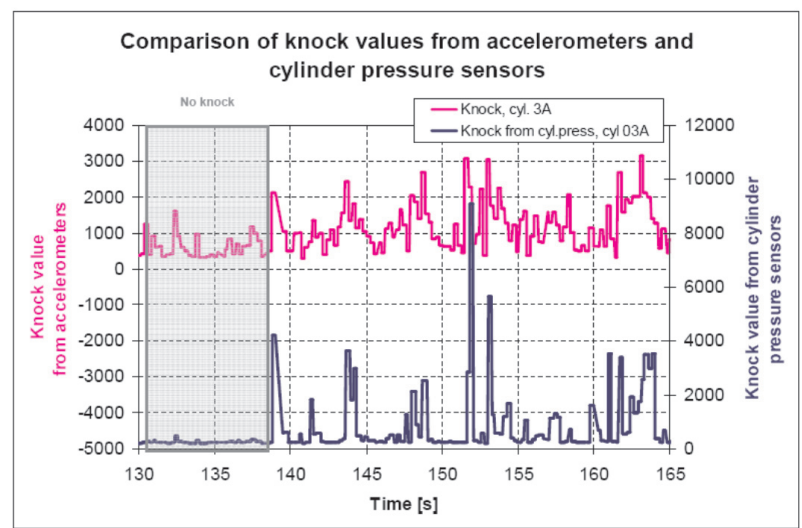

Fig. 21. Comparison knock detection with cylinder pressure sensors to conventional method

Rys. 21. Porównanie wykrywania spalania stukowego metodą konwencjonalna $i$ z wykorzystaniem pomiaru ciśnienia w cylindrze

\section{Application of pressure controlled engine and experience from Pilot project $50 \mathrm{DF}$}

\section{Knock control}

Figure 21 showed secure and quick detection of knock values in comparison to conventional method. For future control strategies the cylinder can work cloth to knock limit for increasing efficiency of engine.

\section{Cylinder balancing}

Figure 22 shows minor $\mathrm{P}_{\max }$ variance at cylinder balancing of all cylinder. The control function compared $\mathrm{P}_{\text {max }}$ single value of cylinder in comparison of average value of all cylinder. Hereby the efficiency of engine will be increased through decreasing mechanical engine impact.

By application of control function "Cylinder balancing" light and medium knocking (Fig. 23) is decreased which increased MTBF of engine.

\section{Conclusion}

An extremely durable long-life- and accuracy cylinder pressure sensor with different dimensions are available for serial production on the market. Pressure controlled engines have a big potential on the market to substitute conventional control methods. After first pilot projects the pressure controlled engines reduces emissions up to $25 \%$ lower $\mathrm{NO}_{\mathrm{x}}$ values, $10 \%$ lower $\mathrm{CO}_{2}$ values and $5 \%$ lower hydrocarbon values.

\section{Bibliography/Literatura}

[1] Kaj Portin, Jenny H.: Gas engine control based on integrared cylinder pressure measurement, 6th Dessau Gas Engine Symposium 2009.

Stefan Neumann - President of IMES GmbH, Germany.

Stefan Neumann - Dyrektor firmy IMES GmbH, Niemcy.

e-mail:neumann@imes.de

\section{Wyrównywanie ciśnienia w cylindrach silnika}

Na rysunku 22 przedstawiono zmiany wartości maksymalnego ciśnienia $w$ cylindrze bez i z procedurą wyrównania ciśnienia. Procedura ta polega na porównaniu maksymalnego ciśnienia danego cylindra z wartością średnią wyznaczoną dla wszystkich cylindrów. Rozwiązanie takie powoduje zwiększenie sprawności ogólnej silnika. Ponadto zastosowanie $\mathrm{w}$ procesie sterowania silnika funkcji wyrównania ciśnienia powoduje wyeliminowanie zjawiska spalania stukowego i zwiększa trwałość silnika (rys. 23).

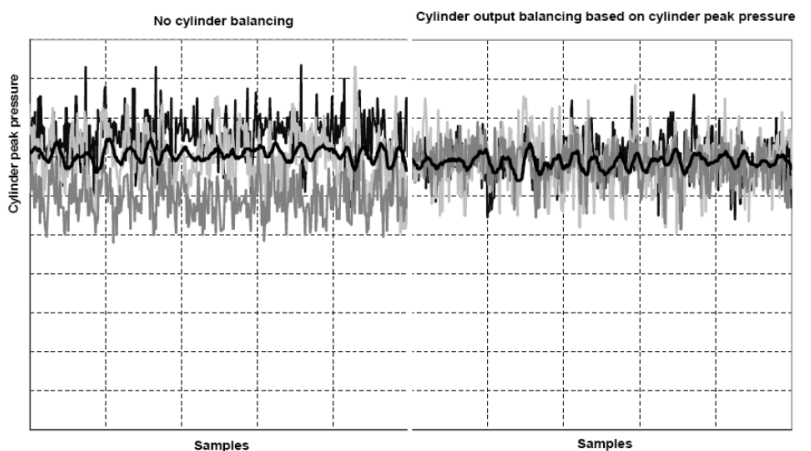

Fig. 22. Comparison $\mathrm{P}_{\max }$ values with- and without balancing Rys. 22. Porównanie zmian maksymalnego ciśnienia $w$ cylindrze z funkcją i bez funkcji wyrównywania ciśnienia

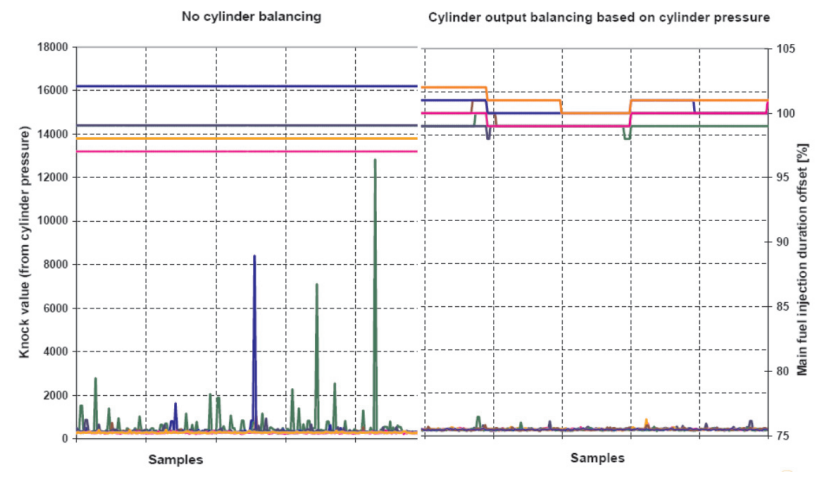

Fig. 23. Knock number of cylinder with- and without balancing Rys. 23. Wykrywanie spalania stukowego bez funkcji i z funkcja wyrównywania ciśnienia $w$ cylindrze

\section{Podsumowanie}

Zaprezentowane w artykule czujniki pomiaru ciśnienia w cylindrze charakteryzują się dużą trwałością i dokładnością; wykonywane są w wersjach o różnych średnicach, mogą być produkowane seryjnie. Przedstawiona metoda sterowania parametrami pracy silnika z wykorzystaniem pomiaru ciśnienia w cylindrze ma znacznie większy potencjał niż metody konwencjonalne. Podczas realizacji pierwszego projektu, dotyczącego sterowania pracą silnika $\mathrm{z}$ wykorzystaniem sygnału z pomiaru ciśnienia w cylindrze, stwierdzono zmniejszenie emisji $\mathrm{NO}_{\mathrm{x}}$ o $25 \%$, $\mathrm{HC}$ o $5 \%$ i $\mathrm{CO}_{2}$ o $10 \%$.

Paper reviewed 